\title{
Teaching NeuroImages: Brain and Skin Involvement in Erdheim-Chester Disease
}

Adrian Budhram, MD, Karen L. Rech, MD, Johann M. Peikert, MD, Scott H. Okuno, MD, Ronald S. Go, MD, Divyanshu Dubey, MD, and W. Oliver Tobin, MB BCh, BAO, PhD

Neurology ${ }^{\circledR}$ 2021;96:e1590-e1592. doi:10.1212/WNL.0000000000011159

Figure 1 Brain MRI in Erdheim-Chester Disease

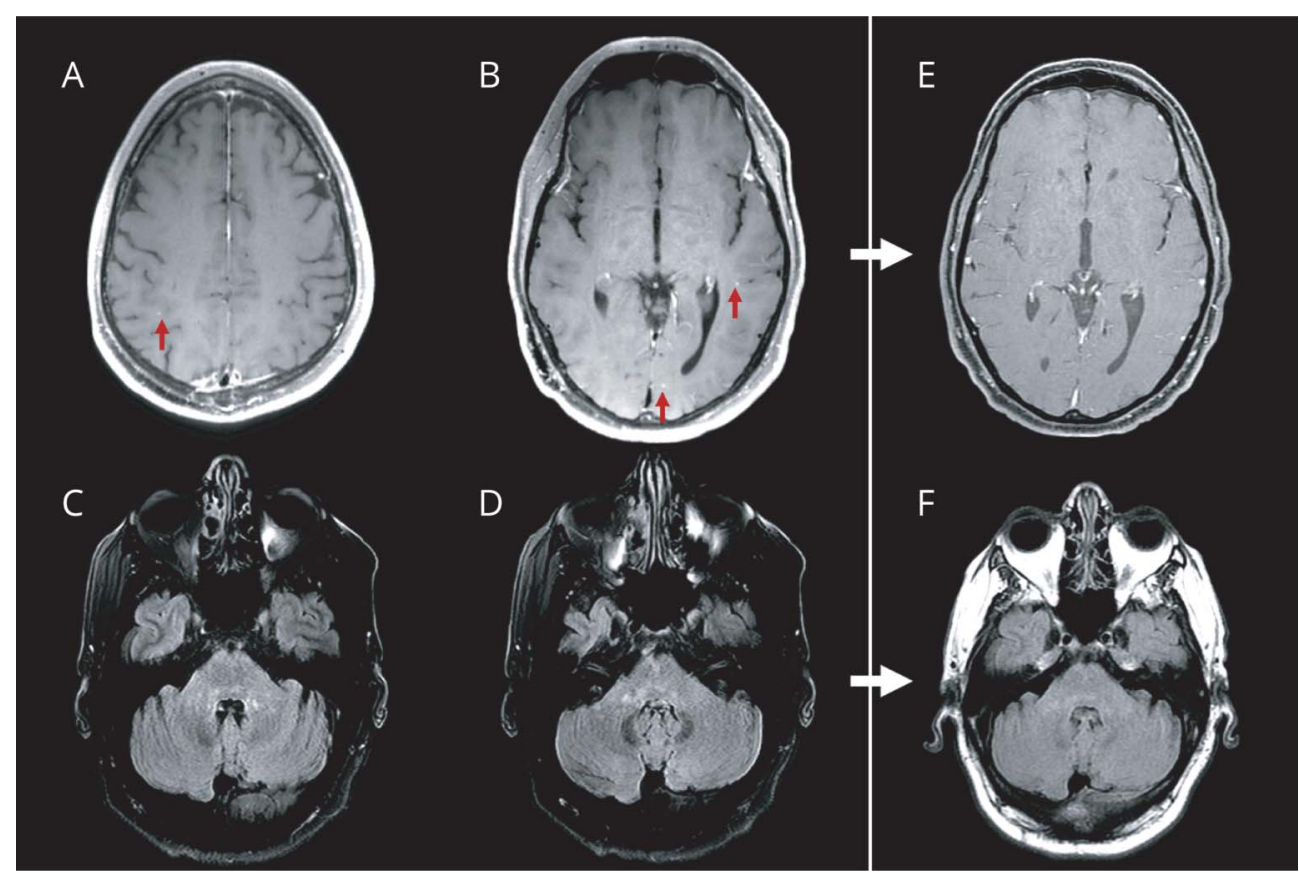

Axial T1-weighted postgadolinium imaging demonstrates punctate enhancing foci supratentorially (A, B, red arrows). Axial T2-fluid-attenuated inversion recovery (FLAIR) imaging demonstrates patchy pontine and middle cerebellar peduncle $T 2$ hyperintensity (C, D). On repeat imaging 4 months after initiation of vemurafenib, punctate gadolinium enhancement has resolved (E), while pontine and middle cerebellar peduncle T2-FLAIR hyperintensity has nearly resolved (F).

A 61-year-old man developed progressive gait imbalance and papular skin lesions over 9 months. He reported fatigue, but no other constitutional symptoms. Neurologic examination revealed gait ataxia. Brain MRI (figure 1, A-D) demonstrated punctate enhancing foci supratentorially and patchy pontine T2 hyperintensity; no pituitary or orbital abnormality was reported. Skin biopsy (figure 2) revealed a histiocytic neoplasm that stained negative for CD1a, weakly positive for S100, and positive for CD163, factor 13A, and BRAF V600E, compatible with Erdheim-Chester disease. ${ }^{1}$ Bone scan and body PET did not demonstrate osseous, cardiac, lung, or retroperitoneal involvement. Vemurafenib was prescribed for Erdheim-Chester disease with brain and skin involvement. ${ }^{2}$ Brain involvement occurs in up to half of patients with Erdheim-Chester disease and most often manifests radiographically as pontine or cerebellar T2 hyperintensity, although multifocal punctate enhancement has also been reported. ${ }^{3,4}$ Skin involvement is observed in approximately one-quarter of patients and

\section{Correspondence}

Dr. Tobin

tobin.oliver@mayo.edu

\section{MORE ONLINE}

$\rightarrow$ Teaching slides

links.lww.com/WNL/ B271

From the Departments of Neurology (A.B., D.D., W.O.T.), Pathology (K.L.R.), and Medicine (R.S.G.), Division of Hematology/Oncology, Mayo Clinic, Rochester, MN; and the Department of Medicine, Division of Dermatology (I.M.P.), and Medical Oncology (S.H.O.), Mayo Clinic Health System, Eau Claire, WI.

Go to Neurology.org/N for full disclosures. Funding information and disclosures deemed relevant by the authors, if any, are provided at the end of the article. 


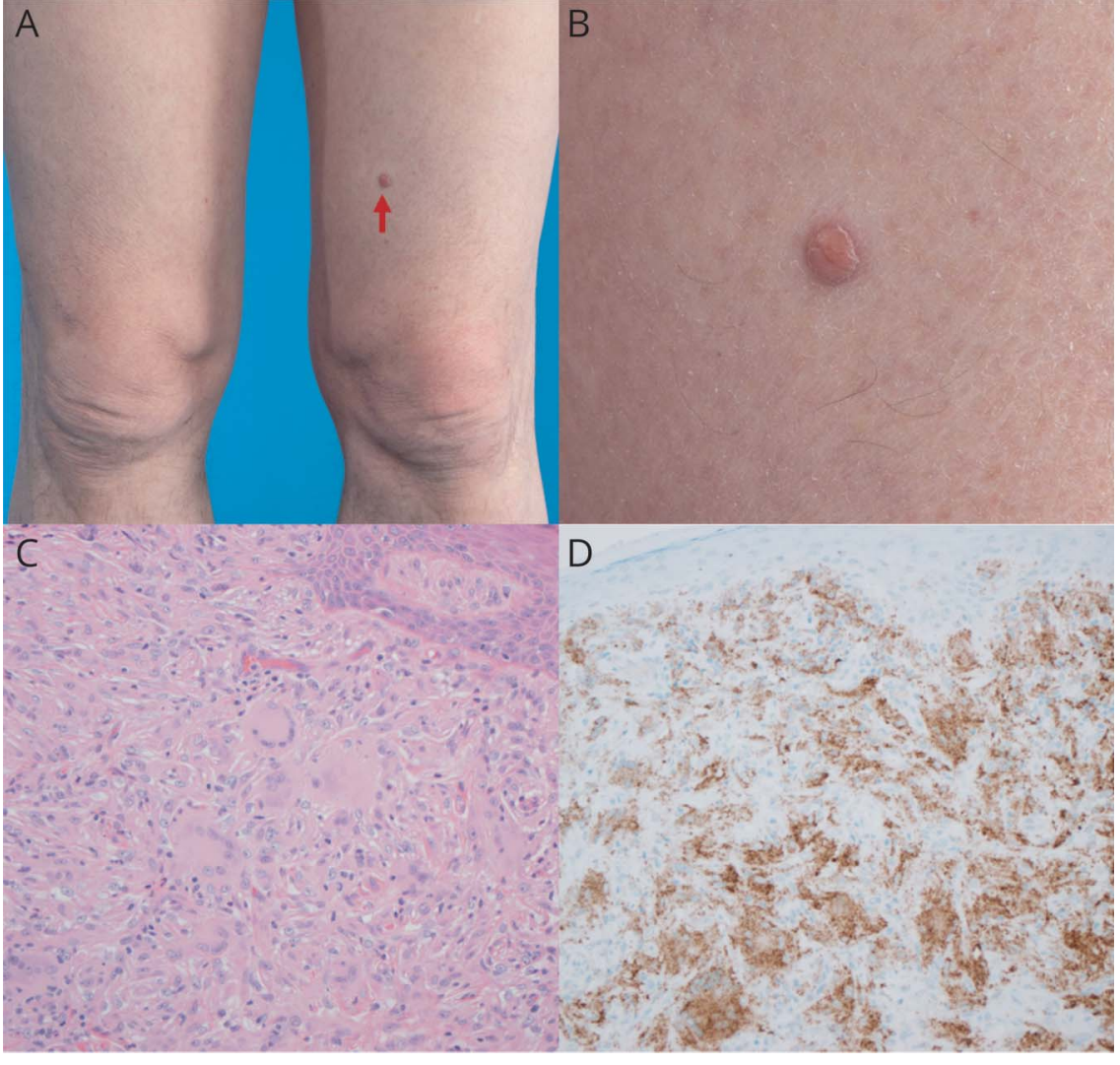

Biopsy of papular skin lesion (A, B) shows dense dermal infiltrate of histiocytes and multinucleated giant cells (C, 200x original magnification). By immunohistochemistry, histiocytic infiltrate is positive for BRAF V600E mutation (D, 200× original magnification). lesions are most commonly xanthelasma-like, although nonfacial cutaneous xanthoma-like lesions as seen in our patient may also occur. ${ }^{5}$ On follow-up 4 months later, the patient's skin lesions had flattened, gadolinium enhancement had resolved, and pontine T2 hyperintensity had nearly resolved (figure 1, E and F), although gait imbalance persisted.

\section{Study Funding}

No targeted funding reported.

\section{Disclosure}

Dr. Budhram, Dr. Rech, Dr. Peikert, Dr. Okuno, and Dr. Go report no disclosures. Dr. Dubey received research support from Center for Multiple Sclerosis and Autoimmune Neurology and Grifols Pharmaceuticals. Dr. Dubey has consulted for UCB Pharmaceuticals. All compensation for consulting activities is paid directly to Mayo Clinic. Dr. Tobin receives research funding from Mallinckrodt Pharmaceuticals and from the Mayo Clinic Center for MS and Autoimmune Neurology. Go to Neurology.org/N for full disclosures.

\begin{tabular}{|c|c|c|}
\hline Name & Location & Contributions \\
\hline $\begin{array}{l}\text { Adrian } \\
\text { Budhram, MD }\end{array}$ & $\begin{array}{l}\text { Mayo Clinic, } \\
\text { Rochester, MN }\end{array}$ & $\begin{array}{l}\text { Drafted manuscript, analyzed and } \\
\text { interpreted the data, composed } \\
\text { the figures }\end{array}$ \\
\hline $\begin{array}{l}\text { Karen L. Rech, } \\
\text { MD }\end{array}$ & $\begin{array}{l}\text { Mayo Clinic, } \\
\text { Rochester, MN }\end{array}$ & $\begin{array}{l}\text { Interpreted the data, revised the } \\
\text { manuscript for intellectual content }\end{array}$ \\
\hline $\begin{array}{l}\text { Johann M. } \\
\text { Peikert, MD }\end{array}$ & $\begin{array}{l}\text { Mayo Clinic } \\
\text { Health System, } \\
\text { Eau Claire, WI }\end{array}$ & $\begin{array}{l}\text { Interpreted the data, revised the } \\
\text { manuscript for intellectual content }\end{array}$ \\
\hline $\begin{array}{l}\text { Scott H. } \\
\text { Okuno, MD }\end{array}$ & $\begin{array}{l}\text { Mayo Clinic } \\
\text { Health System, } \\
\text { Eau Claire, WI }\end{array}$ & $\begin{array}{l}\text { Interpreted the data, revised the } \\
\text { manuscript for intellectual content }\end{array}$ \\
\hline $\begin{array}{l}\text { Ronald S. Go, } \\
\text { MD }\end{array}$ & $\begin{array}{l}\text { Mayo Clinic, } \\
\text { Rochester, MN }\end{array}$ & $\begin{array}{l}\text { Interpreted the data, revised the } \\
\text { manuscript for intellectual content }\end{array}$ \\
\hline $\begin{array}{l}\text { Divyanshu } \\
\text { Dubey, MD }\end{array}$ & $\begin{array}{l}\text { Mayo Clinic, } \\
\text { Rochester, MN }\end{array}$ & $\begin{array}{l}\text { Interpreted the data, revised the } \\
\text { manuscript for intellectual content }\end{array}$ \\
\hline $\begin{array}{l}\text { W. Oliver } \\
\text { Tobin, MB } \\
\text { BCh, BAO, PhD }\end{array}$ & $\begin{array}{l}\text { Mayo Clinic, } \\
\text { Rochester, MN }\end{array}$ & $\begin{array}{l}\text { Designed and conceptualized } \\
\text { study, analyzed and interpreted } \\
\text { the data, revised the manuscript } \\
\text { for intellectual content, study } \\
\text { supervision }\end{array}$ \\
\hline
\end{tabular}




\section{References}

1. Goyal G, Heaney ML, Collin M, et al. Erdheim-Chester disease: consensus recommendations for the evaluation, diagnosis, and treatment in the molecular era. Blood 2020;135:1929-1945.

2. Haroche J, Cohen-Aubart F, Emile JF, et al. Reproducible and sustained efficacy of targeted therapy with vemurafenib in patients with BRAF(V600E)-mutated ErdheimChester disease. J Clin Oncol 2015;33:411-418.
3. Parks NE, Goyal G, Go RS, Mandrekar J, Tobin WO. Neuroradiologic manifestations of Erdheim-Chester disease. Neurol Clin Pract 2018;8:15-20.

4. Berkman J, Ford C, Johnson E, Malow BA, Aulino JM. Misdiagnosis: CNS Erdheim-Chester disease mimicking CLIPPERS. Neuroradiol J 2018;31: 399-402.

5. Kobic A, Shah KK, Schmitt AR, et al. Erdheim-Chester disease: expanding the spectrum of cutaneous manifestations. Br J Dermatol 2020;182:405-409. 


\section{Neurology}

Teaching NeuroImages: Brain and Skin Involvement in Erdheim-Chester Disease

Adrian Budhram, Karen L. Rech, Johann M. Peikert, et al.

Neurology 2021;96;e1590-e1592 Published Online before print November 9, 2020

DOI 10.1212/WNL.0000000000011159

This information is current as of November 9, 2020

\section{Updated Information \&} Services

References

Subspecialty Collections

Permissions \& Licensing

Reprints including high resolution figures, can be found at: http://n.neurology.org/content/96/11/e1590.full

This article cites 5 articles, 2 of which you can access for free at: http://n.neurology.org/content/96/11/e1590.full\#ref-list-1

This article, along with others on similar topics, appears in the following collection(s):

MRI

http://n.neurology.org/cgi/collection/mri

Information about reproducing this article in parts (figures,tables) or in its entirety can be found online at:

http://www.neurology.org/about/about_the_journal\#permissions

Information about ordering reprints can be found online: http://n.neurology.org/subscribers/advertise

Neurology ${ }^{\circledR}$ is the official journal of the American Academy of Neurology. Published continuously since 1951, it is now a weekly with 48 issues per year. Copyright @ 2020 American Academy of Neurology. All rights reserved. Print ISSN: 0028-3878. Online ISSN: 1526-632X.

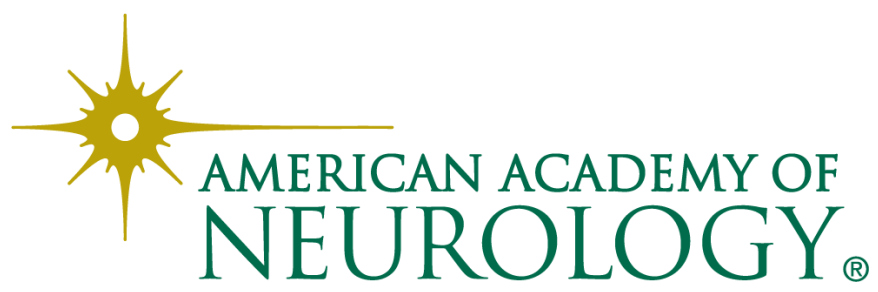

